\title{
Rights of Disabilities to Education, Occupation, Health, Social Welfare, and Accessibility
}

\author{
Yopi Harwinanda Ardesa ${ }^{1 *}$, Prasetyo Catur Utomo², Etanaulia Marsim ${ }^{3}$ \\ 1,2,3 Department of Prosthetic Orthotics, Poltekkes Kemenkes Surakarta, Indonesia \\ Email: yopipoltekkessolo@gmail.com
}

\begin{abstract}
Background: People with disabilities are those with physical or mental limitations in long term. People with disabilities have some rights they deserve such as rights to education, occupation, health, social welfare, and accessibility. Aims study is to describe Rights of Disabilities to Education, Occupation, Health, Social Welfare, and Accessibility. Methods: This research was conducted on December 2019, in Colomadu Sub District using questionnaire with cross-section design. The subject used consisted of 23 quadriplegic persons. Results: Out of 23 quadriplegic persons, the result of analysis showed significant score of 0.236 between people with disabilities and right to education, of 0.167 between people with disabilities and right to occupation, of 0.313 between people with disabilities and right to health, of 0.150 between people with disabilities and right to social welfare, and of 0.762 between people with disabilities and right to accessibility, with $p>0.05$. Conclusion: The rights of people with disabilities (disability people) have not been fulfilled yet in Colomadu Sub District.
\end{abstract}

Keywords: people with disabilities, rights of people with disabilities

\section{INTRODUCTION}

Indonesia is a country that has a disability. Persons with disabilities are people who have physical, mental, intellectual, or sensory limitations for a long time (Lestari, 2017). Based on data from the Colomadu District in 2017, the number of people with disabilities is 64 .

Countries that must be considered what every disability must ask, as required by law no. 8 of 2016 concerning countries maintaining the life of every country, Including persons with disabilities who have legal position and have the right to choose the same people. Article 5 of law no. 8 of 2016 concerning the rights obtained by persons with disabilities.

Education, Authority for Students with Disabilities SDLB, SMPLB, SMALB in Permendiknas No. 01 of 2008, Work in Article 28 Permen number 43 of 1998, Health in UU No. 36 of 2009 Article 139 About Health, Social Welfare, Accessibility in the Decree of the Public
Works Meter no. 468 / KPTS / 1998. Aims study is to describe Rights of Disabilities to Education, Occupation, Health, Social Welfare, and Accessibility.

\section{METHODS}

In this study the description of persons with disabilities uses cross sectional design with descriptive quantitative research type. Quantitative research is to emphasize its analysis of numerical data (numbers) that are processed by statistical methods. The population in this study amounted to 64 . Researchers used a total sampling technique.

Implementation stage the first is selection of research subjects, questionnaire validation was carried out in November to find out the number of valid questionnaires, data collection was carried out by distributing questionnaires to research subjects in December. 


\section{RESULTS}

Characteristics of research subjects can be seen in the following table:

Table 1. Characteristics based on age

\begin{tabular}{lccc}
\hline \multicolumn{2}{c}{ Age } \\
\hline Valid & Frequency & Percent \\
\hline 13 & 1 & $4,3 \%$ \\
19 & 1 & $4,3 \%$ \\
26 & 2 & $8,7 \%$ \\
39 & 1 & $4,3 \%$ \\
43 & 1 & $4,3 \%$ \\
44 & 1 & $4,3 \%$ \\
45 & 1 & $4,3 \%$ \\
46 & 3 & $13 \%$ \\
49 & 2 & $8,7 \%$ \\
51 & 1 & $4,3 \%$ \\
52 & 1 & $4,3 \%$ \\
54 & 1 & $4,3 \%$ \\
59 & 1 & $4,3 \%$ \\
61 & 1 & $4,3 \%$ \\
65 & 1 & $4,3 \%$ \\
66 & 1 & $4,3 \%$ \\
68 & 1 & $4,3 \%$ \\
71 & 1 & $4,3 \%$ \\
& & 1 & $4,3 \%$ \\
\hline
\end{tabular}

Table 2. Characteristics Based on Sex

\begin{tabular}{|c|c|c|c|}
\hline \multicolumn{4}{|c|}{ Sex } \\
\hline & & Frequency & Percent \\
\hline \multirow[t]{3}{*}{ Valid } & Male & 19 & $82,6 \%$ \\
\hline & Female & 4 & $17,4 \%$ \\
\hline & Total & 23 & $100 \%$ \\
\hline
\end{tabular}

Table 3. Characteristics Based on Recidence

\begin{tabular}{llcc}
\hline \multicolumn{3}{c}{ Recidence } \\
\hline Valid & Frequency & Percent \\
& Ngasem & 2 & $8,7 \%$ \\
& Gawanan & 1 & $4,3 \%$ \\
& Malangjiwan & 7 & $30,4 \%$ \\
& Baturan & 1 & $4,3 \%$ \\
& Blulukan & 3 & $13 \%$
\end{tabular}




\begin{tabular}{ccc}
\hline Tohudan & 8 & $34,8 \%$ \\
Bolon & 1 & $4,3 \%$ \\
\hline Total & $\mathbf{2 3}$ & $\mathbf{1 0 0} \%$ \\
\hline The hypothesis in this study looked & use the non parametric spearman test for \\
at the data normality test results. Data & $\begin{array}{l}\text { data that is not normally distributed and } \\
\text { normality test uses Shapiro Wilk because }\end{array}$ & $\begin{array}{l}\text { Pearson correlation for normally } \\
\text { dhe sample is less than 50 and researchers }\end{array}$ \\
distributed data.
\end{tabular}

Table 4. Hypothesis Result Education

\begin{tabular}{cclcc}
\hline \multicolumn{4}{c}{ Correlations } \\
\hline & & Correlation Coefficient & Pendidikan & $\begin{array}{c}\text { Penyandang } \\
\text { Disabilitas }\end{array}$ \\
\hline \multirow{3}{*}{$\begin{array}{c}\text { Spearman's } \\
\text { rho }\end{array}$} & Education & Sig. (2-tailed) & 1,000 &, 236 \\
\cline { 2 - 5 } & & $\mathbf{N}$ & $\mathbf{2 3}$ &, 278 \\
& Disability & Correlation Coefficient &, 236 & 1,000 \\
& People & Sig. (2-tailed) &, 278 & \\
\cline { 2 - 5 } & $\mathbf{N}$ & $\mathbf{2 3}$ & $\mathbf{2 3}$ \\
\hline
\end{tabular}

Based on the table 5 , the Rank meaning that the educational rights for Correlation test (Spearman) results with a persons with disabilities in the Colomadu significant value of 0.236 ( $p>0.05$ ), District are not being fulfilled.

Table 5. Hypothesis Result Profession

\begin{tabular}{cclcc}
\hline & \multicolumn{1}{c}{ Correlations } & \\
\hline & & & $\begin{array}{c}\text { Penyandang } \\
\text { Disabilitas }\end{array}$ & Pekerjaan \\
\hline & Disability & Correlation Coefficient & 1,000 &, 167 \\
People & Sig. (2-tailed) & &, 447 \\
Spearman's & & $\mathbf{N}$ & $\mathbf{2 3}$ & $\mathbf{2 3}$ \\
rho & Profession & Correlation Coefficient &, 167 & 1,000 \\
& & Sig. (2-tailed) &, 447 & $\mathbf{2 3}$ \\
\hline
\end{tabular}

Based on the table 5 , the Rank meaning that the work rights of persons Correlation test (Spearman) results with a with disabilities are not fulfilled in significant value of 0.167 ( $p>0.05$ ), Colomadu District.

Tabel 6. Hypothesis Result Health

\begin{tabular}{cclcc}
\hline \multicolumn{4}{c}{ Correlations } \\
\hline & & $\begin{array}{c}\text { Disability } \\
\text { People }\end{array}$ & Health \\
\hline $\begin{array}{c}\text { Spearman's } \\
\text { rho }\end{array}$ & Disability & Correlatio Coefficient & 1,000 &,- 220 \\
& People & Sig. (2-tailed) & &, 313
\end{tabular}




\begin{tabular}{clcc} 
& $\mathbf{N}$ & $\mathbf{2 3}$ & $\mathbf{2 3}$ \\
\hline Health & Correlatio Coefficient &,- 220 & 1,000 \\
& Sig. (2-tailed) &, 313 & \\
& $\mathbf{N}$ & $\mathbf{2 3}$ & $\mathbf{2 3}$ \\
\hline
\end{tabular}

Based on the table above, the Rank which means that health rights for persons Correlation test (Spearman) results with a with disabilities are not fulfilled in significant value of 0.313 (p> 0.05), Colomadu District.

Table 7. Hypothesis Result Social Welfare

\begin{tabular}{llcc}
\hline \multicolumn{2}{c}{ Correlations } & $\begin{array}{c}\text { Disability } \\
\text { People }\end{array}$ & $\begin{array}{c}\text { Social } \\
\text { Welfare }\end{array}$ \\
\hline Disability & Pearson Correlation & 1 &, 310 \\
people & Sig. (2-tailed) & &, 150 \\
& $\mathbf{N}$ & $\mathbf{2 3}$ & $\mathbf{2 3}$ \\
\multirow{5}{*}{ Social welfare } & Pearson Correlation &, 310 & 1 \\
& Sig. (2-tailed) &, 150 & \\
& $\mathbf{N}$ & $\mathbf{2 3}$ & $\mathbf{2 3}$ \\
\hline
\end{tabular}

Based on the above table, the 0.05), meaning that the social welfare Pearson Correlation test results obtained rights for persons with disabilities are not with a significant value of 0.150 (p> fulfilled in Colomadu District.

Table 8. Hypothesis Result Accessibility

\begin{tabular}{|c|c|c|c|c|}
\hline \multicolumn{5}{|c|}{ Correlations } \\
\hline & & & $\begin{array}{c}\begin{array}{c}\text { Disability } \\
\text { People }\end{array} \\
\end{array}$ & Accessibility \\
\hline \multirow{6}{*}{$\begin{array}{l}\text { Spearman's } \\
\text { rho }\end{array}$} & \multirow[t]{2}{*}{$\begin{array}{l}\text { Disability } \\
\text { People }\end{array}$} & $\begin{array}{l}\text { Correlation } \\
\text { Coefficient }\end{array}$ & 1,000 &,- 067 \\
\hline & & Sig. (2-tailed) & 23 & ,762 \\
\hline & \multirow{4}{*}{ Accessibility } & Correlation & & \\
\hline & & Coefficient &,- 067 & 1,000 \\
\hline & & Sig. (2-tailed) & ,762 & \\
\hline & & $\mathbf{N}$ & 23 & 23 \\
\hline
\end{tabular}

Based on the table above, the Rank was accepted $\mathrm{Ha}$ rejected, thus the Correlation test (Spearman) results with a hypothesis proposed was not proven. significant value of 0.762 (p> 0.05), which means that the right of accessibility for persons with disabilities in Colomadu is not fulfilled.

Based on the hypothesis test that has been done, it can be concluded that Ho

\section{DISCUSSION}

The results of this study indicate that most persons with disabilities in Colomadu District are 45 years old with a percentage of $13.0 \%$, male sex with a 
presentation of $82.6 \%$, and most persons with disabilities come from tohudan village with a percentage of $34.8 \%$.

Everyone has their rights and obligations, the same as people with disabilities who should get the rights they are required to have as explained in Law No. 8 of 2016 that the State guarantees the survival of every citizen, including persons with disabilities who have a position have the same law and human rights, and are explained in detail in Article 5 of Law No. 8 of 2016 concerning several rights obtained by persons with disabilities, namely the right to education (Eta Yuni Lestari, 2017), work, health, social welfare, and accessibility (Thohari, 2014).

In this study shows that the fulfillment of the rights for persons with disabilities in Colomadu District has not been fulfilled, by looking at the results of the hypothesis test $p>0.05$ to find out the rights of persons with disabilities to education that is $p=0.236$, the average of persons with disabilities in the District of Colomadu are older of the 50 not completing their education, they should be able to continue their education up to the undergraduate level, because the Minister of National Education (Permendikbud number 46 of 2016) issued a new regulation in 2014 that all universities in Indonesia, both private and public, are able to open as wide access as possible for people with disabilities to take higher education in accordance with what they want (Soleh, 2014).

Job hypothesis test results obtained $p>0.05$, namely $p=0.167$ where there are still many people with disabilities in Colomadu District who have difficulty finding work because there are still many companies that provide physical requirements, some people with disabilities have found decent jobs, but not a few people with disabilities that doesn't work. Whereas every employer should employ a person with a disability by setting a minimum quota for people with disabilities to get a job, namely 1 person with disabilities per 100 other employees (Shaleh, 2018) (Zulfah Latuconsina, 2014).

Fulfillment of the right to health obtained $p>0.05$ ie $p=0.313$, there are still many who complain about the health services they get, the same thing in Malang, there are still many people who are reluctant or indeed lack information related to reproductive health services for women with disability (Haryono, 2013).

The result of social welfare $p>0.05$ is $\mathrm{p}=0,150$, which means that people with disabilities in Colomadu sub-district have not received social welfare because they are still mostly considered different people by the people around them and village officials who do not care about persons with disabilities. get the same treatment as normal people as explained in the 5th precepts that social welfare for all Indonesian people, but most of them have been able to interact with local residents as well as foreigners they have just met and began to participate in mutual cooperation conducted in their villages mind (Pawestri, 2017).

Hypothesis testing accessibility $\mathrm{p}=$ 0.762 where persons with disabilities have not been able to access public accessibility around them, especially for sidewalks for persons with disabilities and special toilets for persons with disabilities that should have been available in public spaces. Similarly, research on studies of the level of accessibility of public facilities for persons with disabilities in the city of 
Surakarta that people with disabilities cannot yet access the public facilities they need (Susanto, 2018; Syafi'ie, 2014). From the explanation above, it means that the rights of persons with disabilities in Colomadu District have not been fulfilled.

\section{CONCLUSION}

Based on the research that has been done, it can be concluded that the rights of persons with disabilities have not been fulfilled in Colomadu District. Some suggestions that can be made from the results of the study are as follows: For institutions in the District of Colomadu to better optimize the data collection of persons with disabilities and pay more attention to the rights needs of persons with disabilities, especially in the District of Colomadu. This research is expected to help people with disabilities in Colomadu District to get the rights they should get. For institutions this can also be taken into consideration to help meet the needs of assistive devices for people with disabilities in Colomadu District. For researchers who can further use more specific variables to develop research.

\section{REFERENCES}

Haryono, T. Joko, dkk. (2013). Akses Informasi Bagi Perempuan Penyandang Disabilitas Dalam Pelayanan Kesehatan Reproduksi dan Seksualitas, Fakultas Ilmu Sosial dan Ilmu Politik Universitas Airlangga. Vol. 26. Hal. 65-79.

Hikmawati , E, Rusmiyati, C. (2011). Kebutuhan Pelayanan Sosial Penyandang Cacat. Informasi. Vol. 16. Hal. 17-32.
Republik Indonesia, Peraturan Menteri Pendidikan dan Kebudayaan Republik Indonesia Nomor 46 Tahun 2014 Tentang Pendidikan Khusus, Pendidikan Layanan Khusus dan/atau Pembelajaran Layanan Khusus Pada Pendidikan Tinggi.

Republik Indonesia, Peraturan Menteri Pendidikan Nasional Republik Indonesia Nomor 1 Tahun 2008 Tentang Standar Proses Pendidikan Khusus Tunanetra, Tunarungu, Tunagrahita, Tunadaksa, Tunalaras.

Republik Indonesia, Peraturan Pemerintah Republik Indonesia No 43 Tahun 1998 Tentang Upaya Peningkatan Kesejahteraan Sosial Penyandang Cacat.

Republik Indonesia, Undang - Undang Republik Indonesia No 19 Tahun 2011 Tentang Pengesahan Conventional on the Right of Person with Disabilities (Konvensi Mengenai Hak-Hak Disabilitas).

Republik Indonesia, Undang - Undang Republik Indonesia Nomor 36 Tahun 2006 Tentang Kesehatan.

Republik Indonesia, Undang - Undang Republik Indonesia Nomor 8 Tahun 2016 Tentang Penyandang Disabilitas.

Eta Yuni Lestari, S. S. dan N. I. (2017). Pemenuhan Hak Bagi Penyandang Disabilitas Di Kabupaten Semarang Melalui Implementasi Convention on the Rights of Persons With Disabillities (Cprd) Dalam Bidang 
Pendidikan. Integralistik.

Pawestri, A. (2017). Hak penyandang disabilitas dalam perspektif HAM internasional dan nasional. Era Hukum, 2(1), 1-19. Retrieved from http://www.republika.co.id/berita/nas ional/umu

Shaleh, I. (2018). Implementasi Pemenuhan Hak bagi Penyandang Disabilitas Ketenagakerjaan di Semarang. Kanun: Jurnal Ilmu Hukum. https://doi.org/10.24815/kanun.v20i1 .9829

Soleh, A. (2014). Kebijakan Perguruan Tinggi Negeri Yogyakarta Terhadap Penyandang Disabilitas. Jurnal Pendidikan Islam. https://doi.org/10.14421/jpi.2014.31. $1-30$

Syafi'ie, M. (2014). Pemenuhan Aksesibilitas Bagi Penyandang Disabilitas. Journal of Disability Study Inklusi. https://doi.org/10.14421/ijds.010208

Thohari, S. (2014). Pandangan Disabilitas dan Aksesibilitas Fasilitas Publik bagi Penyandang Disabilitas di Kota Malang. Indonesian Journal of Disability Studies, 1(1), 27-37.

Zulfah Latuconsina. (2014). Afirmasi Kebijakan Pemerintah dalam Fasilitasi Kerja bagi Penyandang Disabilitas. Jurnal Penelitian Ilmu Hukum (Research Law Journal). 